\title{
Correction to: Ensuring Sustainability in Forests Through the Participation of Locals: Implications for Extension Education
}

\author{
Mirza Barjees Baig, Juan Pulhin, Loutfy El-Juhany, \\ and Gary S. Straquadine
}

\section{Correction to:}

Chapter 17 in: Behnassi et al. (eds), Climate Change, Food

Security and Natural Resource Management, https://doi.org/10.1007/978-3-319-97091-2_17

Owing to an oversight, one of the chapter author names was published incorrectly as Juhn Pulhin in the previous version. This has been corrected to Juan Pulhin in the book. 